\title{
THE EFFECTIVENESS OF USING AUTHENTIC MATERIALS ON TEACHING SPEAKING FOR ELEVENTH GRADE STUDENTS' OF ISLAMIC HIGH SCHOOL STUDENTS OF MU'ALLIMIN MUHAMMADIYAH YOGYAKARTA IN ACADEMIC YEAR 2013/2014
}

\author{
${ }^{1}$ Ilham \\ 1'Dosen Program Studi Pendidikan Bahasa Inggris, Universitas Muhammadiyah Mataram \\ Email : ilham sila@yahoo.co.id
}

\begin{abstract}
The objectives of this research is to find out whether the using authentic materials on teaching speaking is effective for eleventh grade students of Islamic High School of Mu'allimin Muhammadiyah Yogyakarta in academic year 2013/2014 and whether there is any significance difference between students' speaking ability taught by using authentic materials and the students' speaking who taught by using created materials. This research is experimental research. The participants of the research were the eleventh grade students of Islamic High School of Mu'allimin Muhammadiyah Yogyakarta in academic year 2013/2014. The research instrument used by the researcher was speaking test. The data in the research were mainly gathered through the use of pre-test and post-test. After the data were collected, the writer analyzed them. The researcher used SPSS 16.0 to analyze the students' speaking ability between the experimental group and the control group after the authentic materials was applied. Seeing from the finding of the research, it shows that there is a difference scores got by the students in the experimental group and in the control group after the authentic material was applied. In the pre-test result, the mean of the experimental group was 58.85 and 58.94 for the control group. In post-test, after the authentic material was applied, the mean of the experimental group became 73.94 and 63.15 for the control group. It can be seen that the mean of the experimental group was higher than the control group in post-test. Seeing from the comparison of mean between the experimental group and the control group, it can be known that teaching speaking by using authentic material is effective. In order to find the answer of the hypothesis, certain statistics was used. The analysis of hypothesis testing was conducted using ANCOVA. From the computation, it was known that the significance of value was $0.029<0.05$, then the null hypothesis $(\mathrm{Ho})$ is rejected. Therefore, the hypothesis shows that there is a significance difference between students taught using authentic material and those taught without using created material is accepted
\end{abstract}

Keywords: Authentic Material, Teaching Speaking, Speaking Ability

\section{INTRODUCTION}

Materials are important as a means of helping teachers to understand and apply the theories of language learning, and this importance means that they have become a focus of study in their own right. A teacher should have some creative ideas in designing teaching materials. The material and aids which are used by teacher to make his teaching very effective is called teaching aids and instructional material. Patel and Jain (2008: 57) suggest that a teacher should select teaching material and instructional according the objectives decided by teachers.

Authentic materials come in different forms, newspaper and magazine articles for example, poems and short stories etc, but in addition to these print based authentic materials, the rapid development of computer technology. Richards (2001: 252) divides the materials into two kinds namely authentic and created materials. Richards elaborates an authentic material refers to the use in teaching of texts, photographs, video selections, and other teaching resources that were not specially prepared for pedagogical purposes.

Paedagoria, September 2016, ISSN 2086-6356
Created material refers to the textbooks and other specially developed instructional resources. Authentic material is different to another material. It was developed by teachers when they see that technology has important role in teaching and learning. This case will be interesting if it is integrated to the teaching and learning. A teacher collaborate the function of technology to the learning process.

Based on the understanding of authentic material above, the researcher places it into teaching and learning for Islamic High School of Mu'allimin Muhammadiyah. Institutionally, Islamic High School of Mu'allimin Muhammadiyah as one of Muhammadiyah's school that carries out and creates the students or called as cadres to teach the Muhammadiyah comprehension of religion, explains the Islamic teaching culturally.

Therefore, teaching speaking by using authentic material, an English teacher should find a way how to make the students practice and communicate their own English language. Harmer (2007: 123) points out some reasons for teaching speaking in the classroom. Firstly, speaking activities provide rehearsal opportunities-

Vol. 14, No. 2 
chances to practice real-life speaking in the safety of the classroom. Secondly, speaking tasks in which students try to use any or all of the languages they know provide feedback for both the teacher and the students.

Good teaching speaking activities can and should be extremely engaging for the students. Students who get on with each other, and whose English is at an appropriate level, will often participate freely and enthusiastically if the teacher gives them a suitable topic and task. But problem that occurs more often than any of these is the natural reluctance of some students to speak and to tale part in.

In this research, the researcher, English teachers and the school employees will work collaboratively to encourage students' speaking skill by designing some actions. This research will be carried out to encourage the speaking skill.

The researcher conducts this research because of some reasons:

1. Some experts argue that speaking can be utilized as a bridge to enrich students' knowledge, competence and performance.

2. Most students are low motivated in learning English because of teacher still apply created material, so the researcher wants to shows that authentic material can encourage students' motivation in learning English in particularly speaking English.

3. Most of the students still mispronounce and less of mastering English vocabulary therefore the researcher wants to enhance students' pronunciation skill and enrich students' vocabularies.

Then, the writer expects that this study will give useful contributions benefit for the following parties to the stakeholders such as for English teacher, students, educational institutions, and other researcher.

\section{REVIEW OF RELATED LITERATURE \\ A. Review of Related Theories \\ 1. Authentic text and authentic Material}

An authentic text as real language refers to the language that written based on the real situation or phenomenon. It sometime appeared in the magazines, newspapers, pamphlets, brochures, videos, audios, etc. They are contains some information such as news, issues, stories, experience, picture, advertisement, etc. It explains also the dynamic information that occurred in real life.

They are designed for native speakers; which are real texts; designed not for language students, but for the speakers of the language". In this case, Marley and Guariento (2001: 347) also say that he or she learning the 'real language' that they are in touch with a living, the target language as it is used by the community which speaks it. So, an authentic text is related to the real text in teaching and learning. It means that the text from a video, an audio, a magazine, a newspaper, or a brochure and a pamphlet as the media of learning.

The term authentic material has been defined in different ways throughout the literature. According to Richards and Schmidt (2002: 42) explain an authentic materials in language teaching, the use of materials that were not originally developed for pedagogical purposes, such as the use of magazines, newspapers, advertisements, news reports, or songs. Such materials are often thought to contain more realistic and natural examples of language use than those found in textbooks and other specially developed teaching materials.

So, authentic materials are real materials that the students can find in their real life. They help students to gain their chance to exposure and acquire the language. The real cultural content of many authentic materials encourages involvement and comparisons (especially in multicultural group).

There are many kind sources of authentic materials (whether spoken or written) we can get it. We can take from magazines, newspapers, brochures, pamphlet, comics, leaflet, etc. In today's globalized world, Tamo (2009: 75 ) points out the examples abound, but the most commonly used perhaps are: newspapers, TV programs, menus, magazines, the internet, movies, songs, brochures, comics, literature (novels, poems and short stories), advertisements for events, course catalogues from schools and so forth.

In this case, most of teacher in Indonesia commonly used videos, audios, magazines, newspapers, brochures, pamphlet, and so forth. Those are to be found easily and discuss about the around realities.

\section{Authentic materials and Teaching speaking}

As with any other type of classroom procedure, teachers need to play a number of different roles during the speaking activities. However, according to Harmer (2001: 275-276) there are suggestions if we are trying to get students to speak fluently. First, prompter, a teacher can leaves them to struggle out of such situation on their own. Second, participant, teacher should be a good animator when asking the students to produce the language. However, teachers may want to participate to help students understanding about the materials. Third, feedback provider, the vexed of when and how to give feedback in speaking activities in answering by considering carefully the effect of possible different approach.

In teaching and learning process, there are some steps that a teacher does in conducting the materials. It may covers three phases of teaching activity: pre-teaching activity intended to arouse 
the learner's interest to study; during teaching activity intended to lead the learner to master the topic being discussed; and post teaching activity intended to evaluate what the learner has already acquired.

\section{a. Pre activities}

Pre-activities means that the teacher activity in giving some the background information of the materials. Firstly, the teaching and learning process started by say greeting to the students as an opening speech in each meeting, asking their condition in order to know whether they ready to learn or not, checking attendance list in order to know how many students attend in the classroom during teaching and learning. The next was warming up. It is to stimuli and to engage the students focusing on their mind to the lesson. Warming up was meant to introduce the students to the topic that was going to be discussed.

\section{b. During activities}

There are some activities during teaching and learning process. A teacher will explore the materials that are going to be taught, design and manage the classroom. The teacher started to explore the material in order the students have understanding about the material. A teacher explains the material is to be taught, elaborates objectively what the material is.

The next activity, a teacher asks some questions to the students. A teacher tries to know how far the students understanding about the material. Furthermore, discusses the material, a teacher gives the students chance to responds and expresses about the material orally. So, the students used to express their ideas, opinions, and comments about the material.

\section{c. Post activities}

In this activity, a teacher reflected the material during teaching and learning process. Reflecting means that the students easier to remember and understand the material. Then, a teacher take a note and conclusions, tries to evaluate how far the effectiveness of the material during teaching and learning process and gave a motivation to the students in order to the students will be spirit and study hard.

\section{Hypothesis}

The hypothesis in this research can be formulated as follow: there is a significant difference on students' speaking ability between those who are taught by using authentic materials and those who are taught by using created materials.

\section{RESEARCH METHODOLOGY}

This research was conducted at Islamic high school of Mu'allimin Muhammadiyah Yogyakarta. It was located on Letjen S Parman street No. 68, Yogyakarta. It was conducted in two months, from $8^{\text {th }}$ February to $31^{\text {th }}$ March, 2014. In this study, the researcher used a quasiexperimental research. It will find out the effectiveness of using authentic materials towards students' speaking ability. According to Muijs (2004: 26) that quasiexperimental designs are meant to approximate as possible the advantages of true experiment design. While Richards and Schmidt (2002: 436) point out that quasi-experimental design is a research design that does not meet the most stringent criteria of external and internal validity.

\section{A. Techniques for Collection Data}

In collecting the data, the researcher used the test such as pre-test and post-test. There were three stages to conduct the data collection: pre-test, treatment, and post test.

\section{Pre-test and Posttest}

Pre-test provides a measure on some attribute or characteristics that you assess for participants in experiments before receiving the treatments (Creswell, 2008: 301). This test was conducted at the beginning of the research, at the first meeting of the research. The pre-test was given to both of the group; control and experimental group, but the treatment was given to the experimental group only. It was done to know the English speaking skill of the students before they get treatments.

The post-test is a measure on some attribute or characteristics that is assessed for participants in experiments after a treatment (Creswell, 2008: $301)$. This test was conducted after the treatments were done or at the end of the research. The posttest was given to both of the group, too. By giving the post-test, the researcher knew the result of the research and it showed whether there is a significant difference between the two groups or not.

\section{Treatment}

In conducting the treatment, there were twelve meetings. In this case, a researcher taught the material to the student during teaching and learning process.

\section{B. Research Instrument, Validity and Reliability}

Research instrument is a tool which is used to measure the natural phenomenon and social phenomenon that is observed. For this study, the instrument was used to collect the data is speaking test. The aim of this test is to find out the students ability to express their opinions, ideas, and arguments in English. In this case, the researcher will evaluate how students spelling, pronunciation, grammar, comprehension, and the fluency in speaking English language.

In order to make a good instrument, there are some requirements that should be fulfilled, they are validity and reliability. 
1. Content Validity

Muijs (2004: 66) assert that the better we know our subject and how the concepts we are using are theoretically defined, the better we will be able to design and instrument that is content valid.

In this research, the content validity as an instrument which is arranged based on the syllabus of the curriculum year XI of the English subject. Content validity is required to be accumulated in order to find out if the data collection procedure is good representation of the content, which required to measure.

2. Reliability
A reliability of a measuring instrument is the degree of consistency with which it measures whatever it is measuring. This quality is essential in any kind of measurement. In this research, the researcher uses inter rater reliability to measure the reliability of the instrument of speaking ability. Inter rater reliability, means that different raters rate performances similarly (Louma, 2004: 179).

In this case, it compares the scores were assessed by two raters. The first rater is the researcher himself and the second rater is a third semester student of postgraduate of Ahmad Dahlan University. The result of reliability is shown as follows:

Table 1.The result of Reliability of the Pretest for the Experimental Class and the Control Class

\begin{tabular}{|c|c|c|c|}
\hline \multicolumn{4}{|c|}{ Correlations } \\
\hline & & Researcher & Scorer \\
\hline \multirow[t]{3}{*}{ Researcher } & Pearson Correlation & 1 & $.922^{\star \pi}$ \\
\hline & Sig. (2-tailed) & & .000 \\
\hline & $\mathrm{N}$ & 67 & 67 \\
\hline \multirow[t]{3}{*}{ Scorer } & Pearson Correlation & $.922^{\times \pi}$ & 1 \\
\hline & Sig. (2-tailed) & .000 & \\
\hline & $\mathrm{N}$ & 67 & 67 \\
\hline
\end{tabular}

${ }^{\star *}$. Correlation is significant at the 0.01 level (2-tailed).

The significant $0.00<0.01$, then the null hypothesis $(\mathrm{Ho})$ was rejected. So this research was reliable.

Table 2.The result of Reliability of the Posttest for the Experimental Class and the Control Class

\begin{tabular}{llcr}
\multicolumn{4}{c}{ Correlations } \\
& \multicolumn{2}{c}{ Researcher } & \multicolumn{1}{c}{ Scorer } \\
\hline Researcher & Pearson Correlation & 1 & $.934^{\star *}$ \\
& Sig. (2-tailed) & & .000 \\
& $\mathrm{~N}$ & 67 & 67 \\
\hline Scorer & Pearson Correlation & $.934^{\star *}$ & 1 \\
& Sig. (2-tailed) & .000 & \\
& $\mathrm{~N}$ & 67 & 67 \\
\hline$* *$ Correlation is significant at the 0.01 level (2-tailed).
\end{tabular}

The significant $0.00<0.01$, then the null hypothesis $(\mathrm{Ho})$ was rejected. So this research was reliable.

\section{Scoring}

In giving a score, the researcher used the scoring form to grade the pre test and post test based on Hughes' argument (Hughes, 2003: 132). Its weight is as follows:

Table 3. Weighting of scoring

\begin{tabular}{ccccccc}
\hline Criteria & Accent & Grammar & Vocabulary & Fluency & Comprehension & Total \\
\hline Weight & $0-4$ & $6-36$ & $4-24$ & $2-12$ & $4-23$ & 99 \\
\hline
\end{tabular}




\section{Techniques for Analyzing Data}

There were two data analysis techniques namely descriptive analysis and inferential analysis. It is discussed as follows:

\section{Descriptive Analysis}

Descriptive analysis indicates general tendencies in the data (mean, median, mode), the spread of score (variance, deviation, and range), or a comparison of how one score relates to all others (Creswell, 2008: 190). In this analysis, Creswell (2008: 195) explains it reports the descriptive statistics calculated for observations and measures at the pre-test or post-test stage of experimental designs.

a. Mean

According to Khotari (2004: 132) the mean is the simple measurement of central tendency and is a widely used measured. Creswell (2008: 192) says a mean is the total of the scores divided by the number of scores. It means that the one statistical technique which describes the average score. To have the mean score in this research, the researcher was counted by using SPSS 16.0. b. Range

Srinagesh (2006: 256) says that the difference in magnitude between the largest and the smallest item in the group is known as the range. The other definition, the range score is the difference between highest and the lowest score to items on an instrument (Creswell, 2008: 193-194). To know the range score in this research, the researcher was counted by using SPSS 16.0.

\section{c. Standard Deviation}

It should also be noted that when the group of numbers is not the whole population but a sample of a possible bigger population, statisticians recommend that we modify the standard deviation into an estimated population standard deviation from random samples.

d. Ideal mean and ideal standard deviation

The mean is to find out whether the score is the normal distribution. To analyze the data of speaking ability, the researcher used the parameters based on the Hughes statement. It can be seen based on the table below:

Table 4. Conversion table

\begin{tabular}{ccccccccccc}
\hline $\begin{array}{c}\text { Total } \\
\text { Score }\end{array}$ & $93-99$ & $83-92$ & $73-82$ & $63-72$ & $53-62$ & $43-52$ & $33-42$ & $26-32$ & $16-25$ \\
\hline FSI Level & $4+$ & 4 & $3+$ & 3 & $2+$ & 2 & $1+$ & 1 & $0+$ \\
\hline
\end{tabular}

Hughes, 2003:133

\section{Inferential Analysis}

According to Singh (2006: 224) inferential statistical analysis involves the process of sampling, the selection for study of a small group that is assumed to be related to the large group from which it is drawn. The inferential analysis includes the following points:

\section{a. Normality}

Normality is a test to know whether the research data are normal or not. The requirement of using Kolmogorov Smirnov test, as a member of parametric statistics, is the data must form normal distribution. For that reason, the researcher has to give evidence whether the data which will be analyzed has normal distribution or not. So, to analyze the data the researcher used SPSS 16.0 to know the significance score or difference, if significance $>0.05$, then the distribution of data are normal and it is able to prove the hypothesis and if the significance < 0.05 , then the distribution of the data are not normal.

\section{b. Homogeneity}

The test of homogeneity aims to find out whether or not the scores of the group have homogenous variance compared with the scores of the other group. Its variance has similar or significant difference. In this case, the researcher used test the homogeneity. The formula of homogeneity testing applied the Levene testing.

If the $P$ Value < the standard error $5 \%$ variance is homogenous.

If the $P$ Value $>$ the standard error 5\% variance is not homogeneous.

\section{c. Testing Hypothesis}

Furthermore Goddard and Melville (2006: 69) say that the purpose of the testing hypothesis is to predict a relationship between variables that can be tested. It means that testing hypothesis that is calculated on the basis of sample data is indicative of significant correlation or not.

In this research, the researcher will find out is there any significance difference students who were taught using authentic materials and those who taught without using authentic materials. It 
can be conducted by seeing the score of probability $(P)$. So, this research used the ANCOVA test to know the differences students' speaking ability between experimental class by using authentic materials and control class without using authentic materials.

\section{RESEARCH FINDINGS AND DISCUSSIONS}

\section{A. Descriptive Analysis}

Using authentic materials on teaching speaking is effective. It is proved by the different result between pretest and post-test. Here is the breakdown:

\section{The result of pre-test}

After observing the teaching learning process in the speaking class, the research gave the pretest items to the students. The pre-test was administered on February, $8^{\text {th }} 2014$ both for the experimental group and for the control group. It was conducted by interviewing the students. Each student answered twelve questions of essay items. The test was intended to know students' ability on speaking English. So, the Comparison result of the Descriptive Statistics between the Post test Score of the Experimental Class and the Post test Score of the Control Class as follows:

\section{Table 5.Comparison the Descriptive Statistics between the Pre test Score of the Experimental Class and the Control Class}

\begin{tabular}{lcc}
\hline \multicolumn{1}{c}{ Data } & Experimental Class & Control Class \\
\hline Number of students & 33 & 34 \\
Mean & 58.85 & 58.94 \\
Minimum & 35 & 36 \\
Maximum & 82 & 78 \\
Standard deviation & 9.497 & 10.003 \\
\hline
\end{tabular}

From the Table 5 above, it shows that the mean score of the experiment class was lower than the control class, the minimum score of the experimental class was lower than the control class, the maximum score of the experimental class is higher than the control class, and the standard deviation of the experimental class is higher than the control class.

\section{The result of post-test}

After conducted the treatment, the researcher gave the posttest items to the students. The post test of the Experimental Class was administered on March, $31^{\text {th }} 2014$ while the control Class was administered on March $29^{\text {th }}, 2014$. It was conducted by interviewing the students. Each student answered twelve questions of essay items. The test was intended to know students' ability on speaking English.

So, the Comparison result of the Descriptive Statistics between the Post test Score of the Experimental Class and the Post test Score of the Control Class as follows:

\section{Table 6. Comparison the Descriptive Statistics between the Post test Score of the Experimental Class} and the Post test Score of the Control Class

\begin{tabular}{lcc}
\hline \multicolumn{1}{c}{ Data } & $\begin{array}{c}\text { Experimental } \\
\text { Class }\end{array}$ & Control Class \\
\hline Number of students & 33 & 34 \\
Mean & 73.94 & 63.15 \\
Minimum & 60 & 49 \\
Maximum & 85 & 75 \\
Standard deviation & 6.694 & 6.616 \\
\hline
\end{tabular}

From the table above, it shows that the mean score of the experiment class was higher than the control class, the minimum score of the experimental class was higher than the control class, the maximum score of the experimental class is higher than the control class, and the standard deviation of the experimental class is higher than the control class.

Paedagoria, September 2016, ISSN 2086-6356

\section{B. Using Authentic Materials}

This research consisted of eight meetings. The first and the last meetings were for the pre-test and the post-test, and six meetings were for treatment. It took 
eight weeks, from February, $8^{\text {th }} 2014$ to March, $31^{\text {th }}$ 2011.

\section{Pre-activities}

Firstly, the teaching and learning process started with the greetings to the students as an opening speech in each meeting, asking their condition in order to know whether they the ready to learn or not, checking attendance in order to know how many students attend in the classroom during teaching and learning. The next was warming up. It was meant to stimulate and to engage the students focusing on their mind to the lesson. Warming up was meant to introduce the students to the topic that was going to be discussed. It was done by giving some questions related to the topic to the students. It took about ten to fifteen minutes.

\section{During activities}

In this stage, the teacher explained the material was to be taught, elaborated objectively what the material is. Then, the teacher asked some questions to the students. He tried to know how far the students comprehension about the material. In this case, the teacher divided the students into some groups, giving the instructions to the students to take a part of the activities, then, they discussed the material. The goals of this activity were to give the students the chance to explain and point out the learning material orally.
So, the students are able to express their ideas, opinions, and comments about the material.

\section{Post-activities}

In this activity, the teacher reflected the material during teaching and learning process. Reflecting means that the students easier to remember and understand the material. Then, the teacher took the note and conclusions, try to evaluate how far the effectiveness of the material during teaching and learning process and gave motivation to the students in order to the students will be spirit and study hard.

\section{The degree of Significance or inferential statistics}

There is a significant difference between students' speaking ability taught using authentic materials and those taught using created materials. In order to prove the statement above, the inferential statistics used by the researcher were the test of normality, the test of homogeneity, and the test of hypothesis. The calculation of the inferential analysis as follows:

\section{Test of Normality}

The normality was found that the distributions of the pre test and the post test in the experimental class and the control class were normal when it was measured based on the level of significance of 0.05 . The calculation result of the pre test and the post test in the experimental class and the control class can be seen into table below:

Table 7. The result of the Normality testing

\begin{tabular}{lcrr}
\hline \multicolumn{1}{c}{ Variables } & $\boldsymbol{P}$ Value & \multicolumn{1}{c}{ A } & \multicolumn{1}{c}{ Statement } \\
\hline Pre Experimental & 0.680 & 0.05 & Normal \\
Post Experimental & 0.727 & 0.05 & Normal \\
Pre Control & 0.587 & 0.05 & Normal \\
Post Control & 1.087 & 0.05 & Normal \\
\hline
\end{tabular}

Based on the table above it was found that Kolmogorov Smirnov calculation both of pre test in experimental class and control class were higher than 0.05 , while pre test in experimental class was $0.680>0.05$ and pre test in control class was $0.587>0.05$. It means that the distribution was normal.

The other one, the result of the post test in the experimental class and the control class were higher than 0.05, where the post test in the experimental class was $0.727>0.05$ and the post test in the control class was $1.087>0.05$. It means that the distribution was normal.

\section{Test of Homogeneity}

The aim of homogeneity testing is to measure whether the numbers of the samples are homogenous or inhomogeneous. To measure it, Levene Statistic was used into the table below: 
Table 8. The result of homogeneity testing

Pre test and post test control and experimental class

\begin{tabular}{ccccc}
\hline $\begin{array}{c}\text { Levene } \\
\text { Statistic }\end{array}$ & df $\mathbf{1}$ & df $\mathbf{2}$ & Sig.(P) & Interpretation \\
\hline .117 & 1 & 65 & .733 & Homogeneous \\
\hline
\end{tabular}

Post test and Pre test control and experimental class

\begin{tabular}{ccccc}
\hline $\begin{array}{c}\text { Levene } \\
\text { Statistic }\end{array}$ & df 1 & df 2 & Sig.(P) & Interpretation \\
\hline .021 & 1 & 65 & .884 & Homogeneous \\
\hline
\end{tabular}

From Table 8 above, the result of the pre test of the experimental and the control class was found the significance value $0.733>0.05$. It means that the variables were homogeneous. Therefore, the result of the posttest of the experimental and the control class was found the significance value $0.884>0.05$. It means that the variables were homogeneous.

3. Test of Hypothesis

Table 9. Levene's test of equality of error Variances

Variable: Post

\begin{tabular}{cccc}
\hline $\mathbf{F}$ & $\mathbf{d f} \mathbf{1}$ & $\mathbf{d f} \mathbf{2}$ & Sig. \\
\hline .001 & 1 & 65 & .969 \\
\hline
\end{tabular}

To know whether authentic material is effective on teaching speaking or not, the researcher calculated the significance by using ANCOVA testing. The result of ANCOVA test can be seen into table below:

Tests the null hypothesis that the error variance of the dependent variable is equal across groups.

a. Design: Intercept + pretest + Method * Pretest

The table above shows the significant of value was $0.969>0.05$, then the null hypothesis (Ho) was accepted. So the error variance of the dependent variable was equal across groups.

Table 10. Test of Between-Subject Effects

\begin{tabular}{lccccc}
\hline \multicolumn{1}{c}{ Source } & $\begin{array}{c}\text { Type III Sum of } \\
\text { Squares }\end{array}$ & Df & Mean Square & F & Sig. \\
\hline Corrected & $2035.505^{\mathrm{a}}$ & 3 & 678.502 & 15.304 & .000 \\
Model & 17.638 & 1 & 17.638 & .398 & .530 \\
Pretest & 222.170 & 1 & 222.170 & 5.011 & .029 \\
Method & 318867.000 & 67 & & & \\
Total & 4828.657 & 66 & & & \\
Corrected & & & & & \\
Total & & & & & \\
\hline
\end{tabular}

Dependent Variable: post test

a. $\mathrm{R}$ Squared $=.176$ (Adjusted R Squared $=.137$ )

This value was less than calculated value of 5.011. It was found that the significance of value was $0.029<0.05$, then the null hypothesis $(\mathrm{Ho})$ is rejected. So, there is a significance difference between students' speaking ability who the taught by using authentic material and students' speaking 
ability those taught by using created material. It means that alternative hypothesis $(\mathrm{Ha})$ was accepted.

\section{Discussions}

This research was done in Islamic High School of Mu'allimin Muhammadiyah Yogyakarta at XI science class 2 which has 33 students and XI science class 3 which has 34 students. These discussions are to calculate the significance difference between the students' speaking ability who taught using authentic materials and those who taught using created materials. Descriptive statistics was applied to describe data of certain object through sample or population without doing analysis and making conclusions to be generalized.

The data got from the result of the post-test of the experimental group and the control group were calculated to get descriptive statistics (see table 4.10). It showed that there was significant increased of between the pretest and the posttest of the experimental class, while the pretest and the posttest of the control class was decreased.

Based on the Kolmogorov Smirnov calculation has found that score of the pretest and the posttest of the experimental and the control class were higher than 0.05 . It means that the data was normal, while the score of homogeneity testing of the pretest and the posttest were higher than 0.05 . It means that the data was homogenous.

Finally, the hypothesis can be proved that there is a significant difference between students' speaking ability who taught using authentic material on teaching speaking and the students who taught using created material. It means that authentic material was a good material to be applied on teaching speaking skill.

\section{CONCLUSIONS}

Based on the result of the research, there are some conclusions which can be drawn:

1. The mean of the pre-test result of the experimental class was 58.85 and the mean of the posttest result of the experimental class was 73.94. It means that the mean of the experimental class was higher after the authentic materials were applied. So, using authentic materials can encourage and stimulate the students in speaking English.

2. There is a significance difference between students' speaking ability who taught by using authentic material and those taught by using created material. It can be seen from the ANCOVA testing result. The result shows that the significance value was $0.029<$ 0.0

\section{BIBLIOGRAPHY}

Creswell, J. W. 2008. Educational Research. New York. Pearson Education.

Goddard and Melville. 2006. Research Methodology; an introduction. Lansdowne. Juta \& Co. Itd.
Harmer, J. 2001. The Practice of English Language Teaching (Third Edition). United Kingdom. Pearson Education.

Harmer, J. 2007. The Practice of English Language Teaching (Fourth Edition). United Kingdom. Pearson Education.

Hughes, Arthur. 2003. Testing for Language Teachers. United Kingdom. Cambridge University Press.

Kothari, C.R. 2004. Research Methodology; Methods and Techniques. New Delhi. New Age international Publisher.

Luoma, Sari 2004. Assessing Speaking. Cambridge: Cambridge University Press

Marley and Guariento. 2001. ELT Journal; Text and Task authenticity in the EFL Classroom. Oxford University Press.

Muijs, D. 2004. Doing Quantitative Research in Education. Great Britain. Athenaeum Press.

Patel and Jain. 2008. English Language Teaching; Methods, Tools, and Techniques. Jaipur. Sunrise Publisher.

Richards. 2001. Curriculum Development in Language Teaching. USA. Cambridge University Press.

Richards and Schmidt. 2002. Longman Dictionary of Language Teaching and Applied Linguistics. New York. Pearson education Limited.

Singh, Y.K. 2006. Fundamental of Research Methodology and Statistics. New Delhi. New Age International Publisher.

Srinagesh, K. 2006. The Principles of Experimental Research. USA. Elsevier.

Tamo, D. 2009. Article; the use of Authentic Material in Classroo 